\title{
HUBUNGAN KEPATUHAN PERAWAT MELAKSANAKAN STANDAR PROSEDUR OPERASIONAL PERAWATAN KATETER MENETAP DENGAN ANGKA KEJADIAN INFEKSI SALURAN KEMIH
}

\author{
Maria Karolina Selano1, Ranis Nyadin Panjaitan², Sofyan Budi Raharjo ${ }^{3}$ \\ Sekolah Tinggi Ilmu Kesehatan Elisabeth Semarang ${ }^{1,2}$, Jln. Kawi No. 11, Semarang, (024)8412729 \\ Rumah Sakit St. Elisabeth Semarang ${ }^{3}$, Jln. Kawi No. 11, Semarang, (024)8412729 \\ Email: mariaselano100284@gmail.com (Telp: 085291911978)
}

\begin{abstract}
ABSTRAK
Latar Belakang : Menurut National Kidney and Urologic Disease Information Clearinghouse (NKUDIC) Infeksi saluran kemih merupakan penyakit infeksi tersering kedua setelah infeksi saluran napas dengan jumlah kasus sebanyak 8,3 juta setiap tahun. Kejadian infeksi saluran kemih merupakan $40 \%$ dari seluruh infeksi nosokomial dan $80 \%$ infeksi saluran kemih terjadi sesudah instrumentasi terutama oleh kateterisasi.Pelaksanaan pencegahan infeksi nosokomial oleh perawat berkaitan dengan kepatuhan. Kepatuhan merupakan perilaku positif yang diperlihatkan seseorang saat mengarah ke tujuan terapeutik yang ditentukan bersama. Penelitian ini bertujuan untuk mengetahui hubungan kepatuhan perawat dalam menjalankan standar prosedur operasional perawatan kateter menetap dengan angka kejadian infeksi saluran kemih. Metode : Desain penelitian yang digunakan dalam penelitian ini adalahdeskriptif analitik dengan pendekatan cross sectional. Tehnik pengambilan sampel menggunakan proportional simple random sampling dengan jumlah sampel sebanyak 51 responden yang memenuhi kriteria inklusi dan eksklusi.Analisis data menggunakan uji alternatif fisher's exact test. Hasil :Hasil uji fisher didapatkan $p$ value $=0,048(<0,05)$ pada kepatuhan perawat dan angka kejadian infeksi saluran kemih.KejadianISKadalah11 (21,6\%) pasien, sementara pasien yang tidak mengalami ISK adalah sebanyak 40 responden $(78,4 \%)$. Tingkat kepatuhan SPO perawatan kateter tinggi sebanyak 12 responden $(23,5 \%)$, tingkat kepatuhan SPO perawatan kateter sedang sebanyak 39 responden $(64,7 \%)$. Simpulan : Terdapat hubungan yang signifikan antara kepatuhan perawat dalam menjalankan standar prosedur operasional perawatan kateter menetap dengan angka kejadian infeksi saluran kemih.
\end{abstract}

Kata kunci: kepatuhan perawat; standar prosedur operasional; perawatan kateter; infeksi saluran kemih.

\begin{abstract}
Background: According to National Kidney and Urologic Disease Information Clearinghouse (NKUDIC) Urinary tract infection is the most second common infectious disease after respiratory tract infection with a total of 8.3 million cases each year. The incident ofurinary tract infections is $40 \%$ of all nosocomial infections and $80 \%$ of urinary tract infections occur due to instrumentation especially by catheterization. Carring of prevention to nosocomialinfection by nurses deals with compliance. Compliance is a positive attitude that is show by someone shows when heading to a determined jointof therapeutic goal.This study discusses the relationship of nurse assistance in carring out standard operational procedures of catheter persistent care with the incidence of urinary tract infections. Method: The research design used in this study was descriptive analytic with a cross sectional approach. The sampling technique used proportional simple random sampling with a total sample of 51 respondents who meet the inclusion and exclusion criteria. Data analysis used alternative test fisher's exact test. Results: Fisher test results is obtained $p$ value $=0.048(<0.05)$ on nurse compliance and the incidence of urinary tract infections. UTI incidence is $11(21.6 \%)$ patients, while patients who do not experience UTI are 40 respondents $(78.4 \%)$. The level of compliance with SPO for high catheter care is 12 respondents $(23.5 \%)$, the level of compliance with SPO for moderate catheter care is 39 respondents $(64.7 \%)$. Conclusion: There is a significant relationship between nurses' compliance in carrying out standard operational procedures of catheter persistent care and the incidence of urinary tract infections.
\end{abstract}

Keywords: nurses' compliance; standard operational procedure; catheter persistent care; urinary tract infection. 


\section{LATAR BELAKANG}

Infeksi nosokomial adalah suatu infeksi yang muncul selama seseorang tersebut dirawat atau setelah selesai dirawat. Seorang pasien yang mengalami infeksi nosokomial baru akan menunjukkan gejala infeksi setelah 72 jam dirawat di rumah sakit, sedangkan pasien yang menunjukkan gejala infeksi $<72$ jam setelah di rawat di rumah sakit belum dapat dikatakan infeksi nosokomial (Nursalam, 2009).

Infeksi nosokomial terjadi di seluruh dunia, baik di negara sedang berkembang maupun negara maju. Berbagai penelitian yang dilakukan di seluruh dunia menunjukkan bahwa infeksi nosokomial merupakan penyebab utama morbiditas dan mortalitas. Selain itu, infeksi nosokomial dapat menambah keparahan penyakit dan stress emosional yang dapat mengurangi kualitas hidup.Menurut data Badan Kesehatan Dunia (WHO) tahun 2006 menunjukkan bahwa sekitar $8,7 \%$ dari 55 rumah sakit dari 14 negara di Eropa, Timur Tengah, dan Asia Tenggara dan pasifik terdapat infeksi nosokomial dengan Asia Tenggara sebanyak 10\%(Nugraheni, tono, \& Winarni, 2012)

Infeksi nosokomial yang paling sering terjadi adalah ISK yaitu sekitar $40-60 \%$ dari seluruh infeksi nosokomial yang dapat terjadi di rumah sakit setiap tahunnya. Penyakit infeksi saluran kemih sering terjadi di rumah sakit seluruh dunia dengan angka kejadian $80 \%$ akibat katerisasi (Darmadi, 2008).

Kateterisasi perkemihan adalah tindakan memasukkan selang karet atau plastik melalui uretra ke dalam kandung kemih untuk mengeluarkan air kemih yang terdapat di dalamnya. Keberadaan kateter didalam saluran kemih dianggap benda asing, akibatnya kondisi menetapnya kateter urine yang terpasang di saluran kemih menjadi media bagi bakteri untuk menjangkau saluran kemih dan kolonisasi (Darmadi, 2008).

Salah satu sumber daya manusia di rumah sakit adalah perawat. Perawat dalam melakukan tindakan keperawatan diharapkan sesuai dengan standar prosedur operasional (SPO) yang berlaku di suatu instansi penyedia pelayanan kesehatan tersebut. Dengan adanya standar prosedur operasional (SPO) dalam praktik keperawatan, maka dapat digunakan sebagai acuan dalam penilaian kepatuhan perawat dalam melaksanakan tindakan keperawatan salah satunya adalah kepatuhan dalam melaksanakan perawatan kateter menetap sesuai dengan standar prosedur operasional (SPO) yang ada.

Penelitian Samad (2012) dinyatakan bahwa ada hubungan yang signifikan antara pemasangan kateter dengan kejadian infeksi saluran kemih. Penelitian ini sejalan dengan penelitian yang dilakukan oleh Kasmad (2010) yang menunjukkan adanya hubungan antara kualitas perawatan kateter dengan kejadian infeksi nosokomial saluran kemih.

Penelitian Rarung (2010) menunjukkan Insiden infeksi saluran kemih meningkat sesuai dengan lamanya pemakaian kateter, bervariasi sekitar $3-33 \%$. Untuk menghindari resiko infeksi saluran kemih, prosedur pemasangan kateter harus steril dan kateter harus bebas dari bakteri. Kejadian infeksi saluran kemih tergantung dari cara pemasangan, pengambilan urin, lama pemakaian dan kualiatas kateter tersebut .

Berdasarkan penjelasan diatas maka peneliti melakukan penelitian dengan tujuan untuk mengetahui hubungan kepatuhan melaksanakan standar prosedur operasional perawatan kateter menetap dengan angka kejadian infeksi saluran kemih.

\section{METODE}

Penelitian ini menggunakan metode kuantitatif dengan desain penelitian deskriptif menggunakan pendekatan cross sectional untuk mempelajari hubungan kepatuhan melaksanakan standar prosedur operasional perawatan kateter menetap dengan angka kejadian infeksi saluran kemih. Cara pengumpulan data dengan observasi menggunakan SPO perawatan kateter menetap.

Populasi dalam penelitian ini adalah seluruh perawat di ruang rawat inap penyakit dalam yang berjumlah 59 perawat. Teknik pengambilan sampel menggunakan proportional simple randomsampling dengan kriteria sampel adalah perawat pelaksana di 
ruang rawat inap penyakit dalam yang berjumlah 51 responden. Penelitian dilaksanakan pada tanggal 04 - 24 Agustus 2016.

Analisa data yang digunakan adalah analisa univariat untuk mendeskripsikan kepatuhan perawat dalam menjalankan standar prosedur operasional perawatan kateter menetap dan mengidentifikasi kejadian infeksi saluran kemih. Untuk analisa bivariat untuk menganalisa hubungan kepatuhan melaksanakan standar prosedur operasional perawatan kateter menetap dengan angka kejadian infeksi saluran kemih dengan menggunakan SPSS 21. Uji yang digunakan adalah uji fisher's exact test.

Etika penelitian yang dilakukan yaitu peneliti menjaga kerahasiaan hasilpenelitian baik informasi maupun masalah lain yang menyangkut privasi responden serta peneliti memberikan jaminan kepada responden dalam penelitian dengan tidak mencantumkan nama responden pada lembar observasi tetapi memberikan kode atau inisial. Setelah data diperoleh, peneliti melakukan pengolahan data dengan menggunakan beberapa tahap.

Tahap pertama dari penelitian ini adalah editing untuk memeriksa kembali kelengkapan lembar SPO perawatan kateter menetap yang digunakan.Tahap kedua yang dilakukan yaitu pemberian kode pada jawaban responden. Untuk variabel bebas adalah kepatuhan, kode 1 : rendah (bila hanya melakukan 1-6 dari 12 langkah SPO perawatan kateter), 2 : sedang ( bila melakukan 1 - 9 dari 12 langkah perawatan kateter), 3 : tinggi (bila melakukan 1 - 12 dari 12 langkah SPO perawatan kateter). Untuk variabel terikat adalah kejadian infeksi saluran kemih, kodenya 1 : ISK, 2 : Tidak ISK.

Tahap ketiga adalah memasukkan data menggunakan SPSS 21. Tahap keempat adalah tabulating atau mengelompokkan ke dalam suatu data tertentu berbentuk grafik atau bagan dan pada tahap yang terakhir peneliti mengecek kembali data untuk melihat kemungkinan adanya kesalahan - kesalahan kode atau ketidaklengkapan, kemudian dilakukan pembetulan atau koreksi.

\section{HASILPENELITIAN}

Gambaran umum yang diamati berdasarkan analisis data adalah usia, pendidikan, masa kerja, jenis kelamin. Didapatkan hasil bahwa dari 51 responden diperoleh, seperti dalam tabel dibawah ini :

Tabel 1. Karakteristik Responden

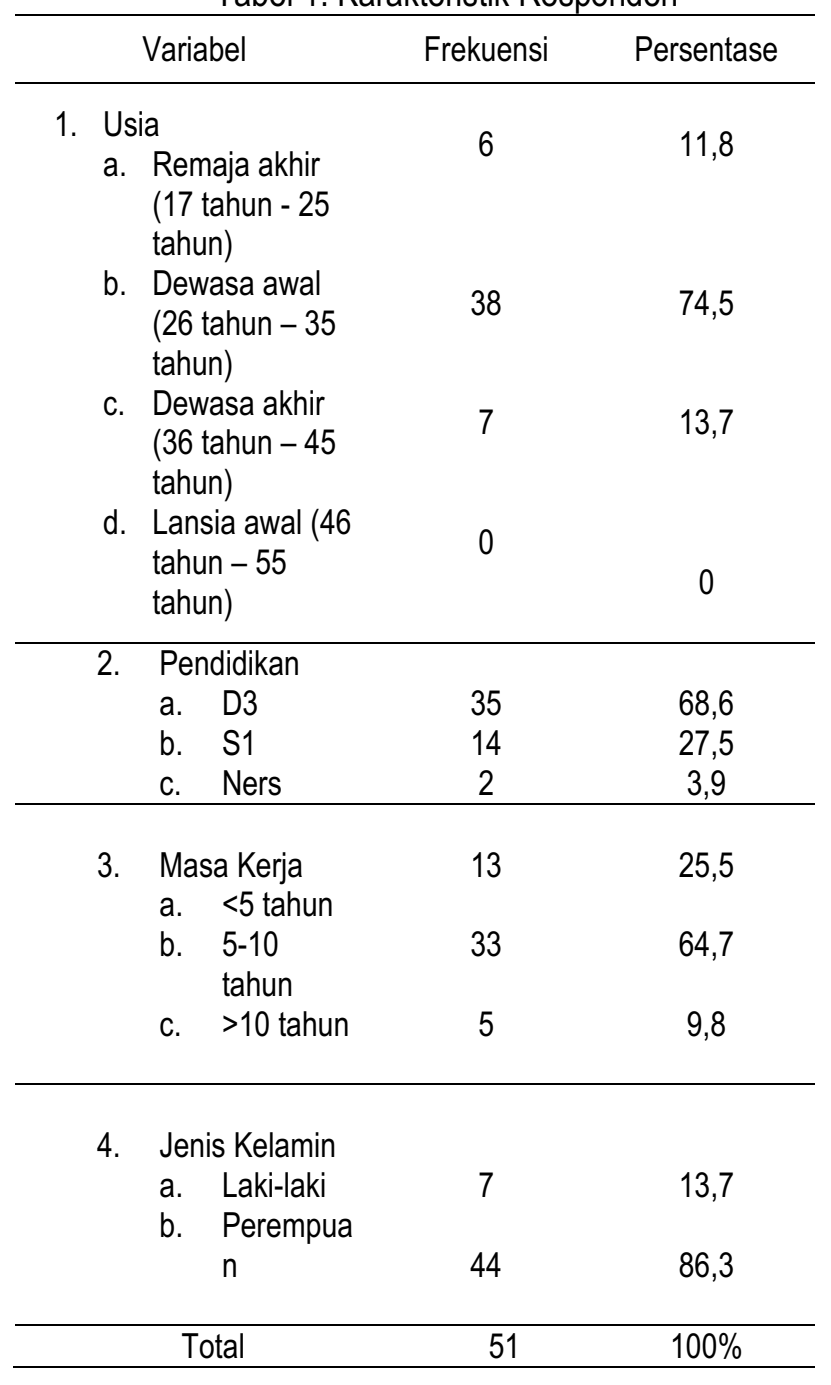

Tabel 1 menunjukan jumlah responden terbanyak yaitu pada dewasa awal usia 26-35 tahun sebanyak 38 responden $(74,5 \%)$, sedangkan jumlah responden terendah yaitu pada masa remaja akhir usia 17-25 tahun sebanyak 6 responden $(11,8 \%)$. Sebagian besar responden memiliki pendidikan D3 yaitu sebanyak 35 responden $(68,6 \%)$, sedangkan jumlah responden terendah yaitu memiliki pendidikan Ners yaitu sebanyak 2 responden $(3,9 \%)$. Masa kerja terbanyak yaitu 5-10 tahun sebanyak 33 responden $(64,7 \%)$, sedangkan 
masa kerja terendah yaitu $>10$ tahun sebanyak 5 responden $(9,8 \%)$. Sebanyak 44 responden $(86,3 \%)$ memiliki jenis kelamin perempuan, sebanyak 7 responden $(13,7 \%)$ memiliki jenis kelamin laki-laki.

Tabel 2.Kepatuhan SPO Perawatan Kateter berdasarkan Usia, Pendidikan, Masa Kerja dan Jenis Kelamin

\begin{tabular}{ccc}
\hline Karakteristik & \multicolumn{2}{c}{ Kepatuhan } \\
\cline { 2 - 3 } responden & Sedang & Tinggi \\
\hline Usia & & \\
$17-25$ tahun & $6(100 \%)$ & $0(0 \%)$ \\
$26-35$ tahun & $29(76,3 \%)$ & $9(23,7 \%)$ \\
$36-45$ tahun & $4(57,1 \%)$ & $3(42,9 \%)$ \\
\hline Pendidikan & & \\
D3 & $28(80 \%)$ & $7(20 \%)$ \\
S1 & $9(64,3 \%)$ & $5(35,7 \%)$ \\
Ners & $2(100 \%)$ & $0(0 \%)$ \\
\hline Masa kerja & & \\
$<5$ tahun & $12(92,3 \%)$ & $1(7,7 \%)$ \\
$5-10$ tahun & $27(81,8 \%)$ & $6(18,2 \%)$ \\
10 tahun & $0(0 \%)$ & $5(100 \%)$ \\
\hline Jenis kelamin & & \\
Laki-laki & $4(57,1 \%)$ & $3(42,9 \%)$ \\
Perempuan & $35(79,5 \%)$ & $9(20,5 \%)$ \\
\hline Total & $39(76,5 \%)$ & $12(23,5 \%)$ \\
\hline
\end{tabular}

Tabel 2 menunjukkan sebagian besar perawat memiliki tingkat kepatuhan sedang pada standar prosedur operasional perawatan kateter adalah kelompok usia 26 - 35 tahun sebanyak 29 responden $(76,3 \%)$ dan kepatuhan tinggi sebanyak 9 responden $(23,7 \%)$.

Pada kelompok pendidikan, sebagian besar responden yang memiliki tingkat kepatuhan sedang pada standar prosedur operasional perawatan kateter adalah responden yang memiliki pendidikan D3 sebanyak 28 responden (80\%) dan kepatuhan tinggi sebanyak 7 responden (20\%).

Pada kelompok masa kerja, sebagian besar responden memiliki tingkat kepatuhan sedang pada standar prosedur operasional perawatan kateter adalah responden yang memiliki masa kerja 5-10 tahun sebanyak 27 responden $(81,8 \%)$ dan kepatuhan tinggi sebanyak 6 responden $(18,2 \%)$.

Sebagian besar responden yang memiliki tingkat kepatuhan sedang pada standar prosedur operasional perawatan kateter adalah responden yang memiliki jenis kelamin perempuan sebanyak 35 responden $(79,5 \%)$ dan kepatuhan tinggi sebanyak 9 responden $(20,5 \%)$, sedangkan laki-laki yang memiliki tingkat kepatuhan sedang sebanyak $4(57,1 \%)$ dan kepatuhan tinggi sebanyak 3 responden $(42,9 \%)$.

Tabel 3 Distribusi Frekuensi Kepatuhan Menjalankan SPOPerawatan Kateter

\begin{tabular}{ccc}
\hline Kepatuhan & $\begin{array}{c}\text { Frekuensi } \\
(\mathrm{f})\end{array}$ & $\begin{array}{c}\text { Persentase } \\
(\%)\end{array}$ \\
\hline Sedang & 39 & 76,5 \\
Tinggi & 12 & 23,5 \\
\hline Total & 51 & 100 \\
\hline
\end{tabular}

Tabel 3 menunjukkan bahwa dari 51 responden didapatkan sebagian besar perawat yang tingkat kepatuhan sedang pada standar prosedur operasional perawatan kateter sebanyak 39 responden $(76,5 \%)$ dan paling sedikit kepatuhan tinggi sebanyak 12 responden $(23,5 \%)$.

Tabel 4 Analisa kejadian ISK dengan lama pemasangan kateter menetap

\begin{tabular}{ccccccc} 
& \multicolumn{5}{c}{ pemasangan kateter menetap } \\
\hline Lama & \multicolumn{5}{c}{ Kejadian ISK } & \multicolumn{3}{c}{ Total } \\
\cline { 2 - 6 } Pemasa & \multicolumn{3}{c}{ ISK } & \multicolumn{4}{c}{ Tidak ISK } & \\
\cline { 2 - 6 } $\begin{array}{c}\text { ngan } \\
\text { Kateter }\end{array}$ & $\mathrm{f}$ & $\%$ & $\mathrm{~F}$ & $\%$ & $\mathrm{f}$ & $\%$ \\
\hline$<72$ Jam & 1 & 2,6 & 38 & 97,4 & 39 & 76,4 \\
>72 Jam & 10 & 83,3 & 2 & 16,7 & 12 & 23,6 \\
\hline Total & 11 & 21,6 & 40 & 78,4 & 51 & 100 \\
\hline
\end{tabular}

Tabel 4 menunjukkan sebagian besar lama pemasangan kateter $<72$ jam sebanyak 39 pasien $(76,4 \%), 1$ pasien $(2,6 \%)$ diantaranya mengalami ISK, sedangkan lama pemasangan kateter $>72$ jam sebanyak 12 pasien $(23,6 \%)$ dan pasien yang mengalami ISK sebanyak 10 pasien (83,3\%).

Hasil yang diperoleh dari analisis bivariat dengan menggunakan uji Fisher's Exact Test, angka signifikannya menunjukkan nilai $\rho$ value $=0.048$ berarti $p$ value $<0.05$, sehingga dapat disimpulkan ada hubungan yang bermakna antara kepatuhan perawat dalam menjalankan standar prosedur operasional perawatan kateter menetap dengan angka kejadian infeksi saluran kemih. 
Tabel 5 Hubungan kepatuhan perawat dalam menjalankan SPO perawatan kateter menetap dengan angka kejadian infeksi saluran kemih

\begin{tabular}{|c|c|c|c|c|c|c|}
\hline \multirow{3}{*}{$\begin{array}{c}\text { Tingkat } \\
\text { kepatuhan } \\
\text { perawat }\end{array}$} & \multicolumn{4}{|c|}{ Kejadian ISK } & \multirow{3}{*}{$\begin{array}{c}\text { Total } \\
(\%)\end{array}$} & \multirow{3}{*}{$\begin{array}{c}p \\
\text { value }\end{array}$} \\
\hline & \multicolumn{2}{|c|}{ ISK } & \multicolumn{2}{|c|}{ Tidak ISK } & & \\
\hline & $f$ & $\%$ & $f$ & $\%$ & & \\
\hline Sedang & 11 & 28,2 & 28 & 71,8 & 39 & 0,048 \\
\hline Tinggi & 0 & & 12 & 100 & $\begin{array}{c}(76,5) \\
12 \\
(23,5)\end{array}$ & \\
\hline Total & 11 & 21,6 & 40 & 78,4 & $\begin{array}{c}51 \\
(100 \%)\end{array}$ & \\
\hline
\end{tabular}

"Uji Fisher's Exact Test

\section{PEMBAHASAN}

\section{Karakteristik perawat pelaksana}

Distribusi usia perawat pelaksana sebagian besar adalah dewasa awal usia 26-35 tahun sebanyak 38 responden(74,5\%), pendidikan perawat pelaksana sebagian besar adalah memiliki pendidikan D3 sebanyak 35 responden $(68,6 \%)$, masa kerja perawat pelaksana sebagian besar memiliki masa kerja 5-10 tahun sebanyak 33 responden $(64,7 \%)$, jenis kelamin perawat pelaksana di ruang rawat inapsebagian besar memiliki jenis kelamin perempuan sebanyak 44 responden $(86,3 \%)$, sisanya sebanyak 7 responden $(13,7 \%)$ memiliki jenis kelamin laki-laki.

Semakin cukup usia seseorang maka tingkat kematangan dan kekuatan seseorang akan lebih matang dalam berpikir dan bekerja. Semakin dewasa seseorang, maka cara berpikir semakin matang dan teratur melakukan suatu tindakan (Notoatmodjo, S. 2007) Semakin matang usia perawat diharapkan dapat meningkatkan kinerja, dan dapat menyalurkan pengetahun dan pengalamannya untuk meningkatkan pelayanan kepada pasien (Rumpea, S. 2010)

Penelitian menyatakan bahwa perilaku seseorang didasari oleh pengetahuan yang diketahuinya, semakin banyak pengetahuan seseorang maka perilakunya lebih baik dari pada seseorang yang pengetahuannya sedikit (Notoatmodjo, S. 2007). Penelitian Haslina (2011) dinyatakan pengetahuan seseorang bisa didapatkan dari pendidikan formal, nonformal dan juga dari pengalaman seseorang (sesuatu yang pernah dialami seseorang tentang sesuatu hal).Pengalaman atau masa kerja adalah keseluruhan pelakaran yang diperoleh seseorang dari peristiwa yang dialami selama perjalanan kerja. Semakin lama seseorang bekerja dalam suatu bidang maka semakin terampil seseorang dalam pekerjaannya(Supratman, 2008).

Penelitian Ulfa (2015) menyatakan faktor internal dan eksternal tidak memiliki pengaruh yang signifikan terhadap kepatuhan perawat dalam melaksanakan SPO pemasangan kateter di RS PKU Muhammadiyah Yogyakarta Unit II. Untuk faktor internal meliputi Jenis kelamin, usia, masa kerja, tingkat pendidikan, pengetahun dan sikap sedangkan faktor eksternal meliputi lingkungan kerja, karakteristik kelompok dan beban kerja. Hasil penelitian mengenai analisis faktor risiko kejadian infeksi saluran kemih (ISK) oleh bakteri uropatogen di puskesmas ciputat dan pamulngan juga dinyatakan tidak ada hubungan yang bermakna antara kejadian ISK dengan umur $(p=1,000)$, tidak ada hubungan antara ISK dengan jenis kelamin $(p=0,068)$ (Sholihah, 2017).

\section{Analisa kejadian ISK dengan lama pemasangan kateter menetap}

Infeksi saluran kemih (ISK) menunjukkan keberadaan mikroorganisme dalam urin dan merupakan penyakit yang sering ditemui. ISK dapat disebabkan oleh bakteri, virus dan jamur. Beberapa faktor yang dapat mencetus terjadinya ISK yaitu litiasis, obstruksi saluran kemih, penyakit ginjal polikistik, nekrosis papilar, DM pasca transplantasi ginjal, nefropati analgesik, penyakit sikle-cell, senggama, kehamilan, konsumsi KB dengan tablet progesterone dan kateterisasi (Enday S. 2009).

Hasil penelitian menunjukkan sebagian besar lama pemasangan kateter $<72$ jam sebanyak 39 pasien $(76,4 \%), 1$ pasien $(2,6 \%)$ diantaranya mengalami ISK, sedangkan lama pemasangan kateter $>72$ jam sebanyak 12 pasien $(23,6 \%)$ dan pasien yang mengalami ISK sebanyak 10 pasien (83,3\%). Infeksi saluran kemih (ISK) pada penelitian ini pada hari ke 3 dan ke 4 sejak pemasangan kateter urine menetap. Hal ini sesuai dengan teori yang dijelaskan bahwa Infeksi nosokomial 
muncul setelah 72 jam seseorang tersebut dirawat atau selesai dirawat, sedangkan pasien yang menunjukkan gejala infeksi $<72$ jam setelah di rawat di rumah sakit belum dapat dikatakan infeksi nosokomial (Nursalam, 2009).

\section{Kepatuhan dalam menjalankan standar prosedur operasional perawatan kateter menetap}

Perawatan kateter adalah suatu tindakan keperawatan dalam memelihara kateter dengan antiseptik untuk membersihkan ujung uretra dan selang kateter bagian luar serta mempertahankan kepatenan kelancaran aliran urin pada sistem drainase kateter. Pasien yang dikateterisasi dapat mengalami infeksi saluran kemih melalui berbagai cara. Perawatan kateter merupakan tindakan yang penting untuk mengontrol infeksi. Perawatan kateter yang salah dapat menyebabkan masuknya mikroorganisme. Daerah yang memiliki risiko masuknya mikroorganisme ini adalah daerahk insersi kateter, kantung drainase, sambungan selang, klep dan sambungan antar selang dan kantung (Potter \& Perry, 2005).

Salah satu faktor yang menyebabkan timbulnya infeksi nosokomial di rumah sakit adalah tindakan pemasangan kateterisasi. Oleh karena itu pasien yang terpasang kateter menetap membutuhkan perawatan khusus. Tindakan keperawatan diarahkan pada tindakan pencegahan infeksi dengan melakukan perawatan kateter setiap hari sesuai dengan prosedur tetap (protap) yang berlaku ditempat perawat tersebut bekerja.

Selama hasil observasi pada point 10 yang mengatakan mengolesi bethadine dari ujung kateter dekat meatus sepanjang $10 \mathrm{~cm}$ dengan arah melingkar, sebanyak 23 responden (45\%) tidak melakukannya. Bethadine-providoneiodine merupakan agens antimikroba yang efektif dalam desinfeksi dan pembersihan kulit yang dibuat dari bahan kimia yang digunakan untuk mencegah terjadinya infeksi. Pada point 8, dimana pada laki-laki: pasien diatur dalam posisi supine, pada perempuan: pasien diatur dalam posisi dorsal recumbent sebanyak 15 responden $(29,4 \%)$ dan pada point 7 yang mengatakan perawat memasang sarung tangan steril sebanyak 9 responden $(17,7 \%)$, masih terdapat beberapa responden tidak melakukannya dan jika di analisa responden yang tidak melakukan point tersebut didapatkan bahwa pasien mengalami infeksi saluran kemih (Potter \& Perry, 2005).

\section{Hubungan kepatuhan perawat dalam menjalankan standar prosedur operasional perawatan kateter menetap dengan angka kejadian infeksi saluran kemih}

Kateterisasi merupakan tindakan memasukkan selang plastik atau karet melalui uretra ke dalam kandung kemih (Potter \& Perry, 2005). Pemasangan kateter semakin lama akan menurunkan sebagian besar daya tahan alami traktus urinarius inferior dengan menyumbat duktus periuretralis, mengiritasi mukosa kandung kemih dan menimbulkan jalur artifisial untuk masuknya kuman (mikroba phatogen) ke dalam kandung kemih (Smeltzer \& Bare, 2001). Kemudian mikroba phatogen tersebut akan berkembang biak dan menyebar melalui darah (bakteremia)dan semakin lama mikroba phatogen tersebut berkembang biak maka akan mengakibatkan kerusakan serta gangguan fungsi organ semakin luas yang akhirnya memunculakn manifestasi klinis yang signifikan untuk diagnosis infeksi saluran kemih (Darmadi, 2008)

Penelitian yang dilakukan Putri, (2015) dinyatakan bahwa lama penggunaan kateter merupakan faktor risiko paling dominan yang berpengaruh terhadap kejadian ISK pada pasien dengan kateter menetap. Pasien dengan lama penggunaan kateter $>3$ hari mempunyai risiko 56,07 kali dapat terkena ISK dibandingkan dengan pasien yang menggunakan kateter $\leq 3$ hari. Uji probabilitas membuktikan bahwa 25\% kejadian ISK pada pasien dengan kateter menetap disebabkan oleh penggunaan kateter $>3$ hari.

Hasil penelitian ini menunjukkan bahwa dari 51 responden terdapat sebanyak 12 responden $(23,5 \%)$ yang menjalankan perawatan kateter memiliki tingkat kepatuhan tinggi dan tidak mengalami ISK sebanyak 40 responden (78,4\%). Sedangkan tingkat kepatuhan sedang sebanyak 39 responden $(64,7 \%)$ dan mengalami infeksi sebanyak 11 responden $(21,6 \%)$. Hasil uji chi-square dengan 
uji alternatif fisher's exact test diperoleh 0,048 $(p<0,05)$ sehingga ada hubungan kepatuhan perawat dalam menjalankan SPO perawatan kateter menetap dengan angka kejadian infeksi saluran kemih.

\section{KESIMPULAN DAN SARAN}

Hasil penelitian ini menunjukkan ada hubungan antara kepatuhan perawat dalam menjalankan standar prosedur operasional perawatan kateter dengan kejadian infeksi saluran kemih dengan angka signifikan $p$ value $=0,042(p$ $<0,05$ ). Hasil penelitian ini dapat menjadi evaluasi pelaksanaan kepatuhan perawat dalam menerapkan SPO perawatan kateter dan menjadi dasar pengambilan kebijakan terkait upaya peningkatan kepatuhan perawat dalam melakukan tindakan keperawatan.

\section{DAFTAR PUSTAKA}

Darmadi. 2008. Infeksi nosokomial problematika dan pengendaliannya. Jakarta; Salemba Medika

Darmadi. 2008. Konsep Dasar Keperawatan. Jakarta: EGC; 2008.

Enday S. 2009. IImu Penyakit dalam Ul: Infeksi saluran kemih pasien dewasa. Jilid ke-2. $5^{\text {th }}$ ed. Jakarta: Interna Publishing;

Haslina 2011. Faktor yang berhubungan dengan kepatuhan perawat dalam menjalankan protap pemasangan Kateter Uretra di Ruang Perawatan Bedah dan Interna RSUD Syekh Yusuf Gowa. Makasar ; Skripsi tidak diterbitkan. Fakultas IImu Keperawatan-UMI.

Kasmad, K., Sujianto, U., \& Hidayati, W. (2010). Hubungan Antara Kualitas Perawatan Kateter Dengan Kejadian Infeksi Nosokomial Saluran Kemih. Nurse Media Journal of Nursing, 1(1). https://doi.org/10.14710/NMJN.V1/1.237

Nursalam, Fransisca B. 2009. Asuhan Keperawatan pada Pasien dengan Gangguan Sistem Perkemihan. Jakarta: Salemba Medika.

Nugraheni, R., tono, S., \& Winarni, S. (2012). Infeksi Nosokomial di RSUD Setjonegoro Kabupaten Wonosobo. Media Kesehatan Masyarakat Indonesia, 11(1), 94-100. https://doi.org/10.14710/MKMI.11.1.94-100

Rarung, M., Obstetri, B., Ginekologi, D., Universitas, K., Ratulangi, S., Sakit, R., \& Kandou, R. D. (n.d.). Perbandingan Pemasangan Kateter Menetap selama 12 dan 24 jam Pasca Seksio Sesarea pada Pencegahan Retensio Urin dan Resiko Infeksi Saluran Kemih. Retrieved from.https://media.neliti.com/media/publicati ons/149796

Rumpea, S. 2010. Hubungan karakteristik perawat dengan tingkat kepatuhan perawat mencuci tangan di rumah sakit columbia Medan: Universitas Darma Agung.

Supratman. 2008. Model - model supervisi keperawatan klinik

Sholihah Hidayatus H. 2017. Analisis faktor risiko kejadian infeksi saluran kemih (ISK) oleh bakteri uropatogen di Puskesmas Ciputat dan Pamulangan.

Putri, R. A., Armiyati, Y., \& Supriyono, M. (2015). Faktor - Faktor Yang Berpengaruh Terhadap Kejadian Infeksi Saluran Kemih Pada Pasien Rawat Inap. In Karya Ilmiah (Vol. 0). Retrieved from http://182.253.197.100/ejournal/index.php/ilmukeperawatan/article/vie w/76

Potter \& Perry, 2005. Buku Ajar Fundamental Keperawatan; Konsep, Proses dan Praktik, Edisi 4. Volume 2. Alih Bahasa : Komalasari. Jakarta : EGC.

Samad, R. A. (2014). Hubungan Antara Pemasangan Kateter Dengan Kejadian Infeksi Saluran Kemih Pada Pasien Di Ruang Rawat Inap Penyakit Dalam Rn Rsud Za Banda Aceh Tahun 2012. Skripsi Fakultas . Retrieved from http://etd.unsyiah.ac.id/index.php?p=show_de tail\&id $=5564$

Smeltzer, S.C \& Bare, B.G. 2001. Buku Ajar Keperawatan Medikal Bedah Brunner \& Suddarth. Edisi 8. Volume 3. Alih bahasa : Waluyo. Jakarta: EGC

Ulfa Maria. 2015. Pengaruh Faktor internal dan eksternal terhadap kepatuhan perawat dalam melaksanakan standar prosedur operasional pemasangan kateter di rumah sakit PKU Muhammadiyah Yogyakarta Unit II. http://repository.umy.ac.id/handle/123456789/ $\underline{2850}$ 